\title{
PENGEMBANGAN PERANGKAT PEMBELAJARAN MODEL INKUIRI TERBIMBING BERBASIS POTENSI LOKAL MATERI STRUKTUR DAN FUNGSI JARINGAN TUMBUHAN
}

\author{
Ahya Mujahidin ${ }^{1}$, Triastono Imam Prasetyo ${ }^{2}$, Siti Imroatul Maslikah ${ }^{3}$ \\ 1,2,3 Jurusan Biologi, Fakultas Matematika dan Ilmu Pengetahuan Alam \\ Universitas Negeri Malang, Jalan Semarang 5 Malang \\ E-mail: ahyamujahidin@gmail.com
}

\begin{abstract}
Local potential can ideally be presented in learning that can support the process of student inquiry. During this time, the majority of teachers are still focusing on textbooks and have not yet optimized their local potential to teach Biology material, including material on the structure and function of plant tissues. This study aims to produce a guided inquiry learning model of Plant Network Structure and Function that is valid, practical, and effective. This research and development uses a 4-D development model by Thiagarajan, but it is only carried out until the develop phase. Research data in the form of quantitative and qualitative data. The results showed that the percentage of learning device validation scores in the form of syllabus, lesson plans, worksheets, and assessment instruments produced an average of $91.92 \%$ (very valid and feasible to use). The practicality test results of the use of learning devices obtained an average percentage of $88.96 \%$ (very practical to use). The effectiveness test data shows that the average score of student competencies is 84.31 . Knowledge domain competence shows students completeness in the knowledge domain competence is $85.18 \%$.
\end{abstract}

Keywords: learning instruments, guided inquiry, local potential, the structure and function of plant tissues

\begin{abstract}
Abstrak: Potensi lokal idealnya dapat dihadirkan dalam pembelajaran yang dapat menunjang proses inkuiri siswa. Selama ini, mayoritas guru masih berfokus pada buku teks dan belum mengoptimalkan potensi lokal untuk membelajarkan materi Biologi, termasuk materi struktur dan fungsi jaringan tumbuhan. Penelitian ini bertujuan untuk menghasilkan perangkat pembelajaran model inkuiri terbimbing materi Struktur dan Fungsi Jaringan Tumbuhan yang valid, praktis, dan efektif. Penelitian dan pengembangan ini menggunakan model pengembangan 4-D oleh Thiagarajan, namun hanya dilakukan sampai tahap develop saja. Data hasil penelitian berupa data kuantitatif dan kualitatif. Hasil menunjukkan bahwa persentase skor validasi perangkat pembelajaran berupa Silabus, RPP, LKS, dan Instrumen Penilaian menghasilkan ratarata sebesar $91,92 \%$ (sangat valid dan layak digunakan). Hasil uji kepraktisan penggunaan perangkat pembelajaran diperoleh persentase rata-rata $88,96 \%$ (sangat praktis digunakan). Data uji keefektifan menunjukkan bahwa skor rata-rata kompetensi siswa sebesar 84,31. Kompetensi ranah pengetahuan menunjukkan ketuntasan siswa pada kompetensi ranah pengetahuan sejumlah $85,18 \%$.
\end{abstract}

Kata kunci: perangkat pembelajaran, inkuiri terbimbing, potensi lokal, struktur dan fungsi jaringan tumbuhan .

Pendidikan yang baik menjadi salah satu faktor penting untuk kemajuan bangsa, karena berfungsi mencerdaskan kehidupan bangsa dan membentuk watak serta peradaban bangsa yang bermartabat. Hal ini dapat ditafsirkan bahwa keberhasilan suatu negara dalam menghadapi tantangan global sangat ditentukan oleh kualitas pendidikan. Kualitas pendidikan yang baik dapat dicapai apabila memperhatikan beberapa komponen dalam kegiatan belajar mengajar. Arikunto (2013) berpendapat bahwa terdapat triangulasi atau hubungan erat tiga komponen proses pembelajaran yaitu tujuan pembelajaran, kegiatan pembelajaran, dan evaluasi. Ketiga komponen ini merupakan bagian yang tidak terpisahkan dan saling berhubungan satu dengan yang lain. Keseluruhan komponen 
pembelajaran yang meliputi tujuan, materi atau bahan ajar, metode, media, dan evaluasi seringkali disebut sebagai perangkat pembelajaran. Menurut Winarni, dkk., (2012) perangkat pembelajaran dibutuhkan dalam kegiatan pembelajaran, karena dapat menciptakan keteraturan tahapan dalam proses belajar yang berlangsung di sekolah.

Perangkat pembelajaran yang digunakan dalam proses pembelajaran tentu mengacu pada suatu kurikulum yang dikembangkan oleh pemerintah sebagai upaya peningkatan kualitas pendidikan. Kurikulum yang dianjurkan oleh pemerintah adalah $\mathrm{Ku}$ rikulum 2013. Pembelajaran pada kurikulum ini menggunakan Pendekatan Saintifik (Scientific Approach). Hasil penelitian Fauziyah, dkk., (2013) menyimpulkan bahwa tahaptahap pendekatan saintifik dapat meningkatkan kemampuan siswa dalam mengamati, menanya, menalar, mencoba, dan mengomunikasikan sehingga berdampak positif terhadap kemampuan soft skill siswa.

Pendekatan Saintifik (Scientific Approach) dalam proses pembelajaran dapat disesuaikan dengan model pembelajaran yang bersifat kontruktivistik, salah satunya adalah model pembelajaran inkuiri (Inquiry Learning). Model pembelajaran ini memiliki beberapa karakteristik yaitu menekankan aktivitas siswa untuk mencari dan menemukan sumber masalah, mencari dan menemukan jawaban sendiri, dan mengembangkan kemampuan intelektual siswa. Bilgin (2009) menggambarkan pembelajaran model Inkuiri Terbimbing (Guided Inquiry) sebagai model pembelajaran yang berpusat pada siswa. Model pembelajaran ini memiliki pengaruh positif terhadap keberhasilan akademik dan mengembangkan keterampilan proses serta sikap ilmiah siswa.

Berdasarkan hasil wawancara dengan guru IPA MTsN 3 Nganjuk pada tanggal 16 Agustus 2016, diketahui bahwa sekolah telah menerapkan Kurikulum 2013 (K13) dalam pelaksanaan pembelajaran sejak awal tahun ajaran 2013/2014. Periode peralihan Kurikulum dari KTSP ke K13 tentu membutuhkan penyesuaian rancangan pelaksanaan pem- belajaran yang disusun dalam bentuk Perangkat Pembelajaran.

Kegiatan wawancara juga dilakukan pada beberapa siswa kelas IX yaitu beberapa siswa yang sudah mengikuti pembelajaran materi Struktur dan Fungsi Jaringan Tumbuhan, diketahui bahwa proses pembelajaran pada materi ini dilakukan oleh guru belum memunculkan sintaks pembelajaran model Inkuiri sebagaimana model pembelajaran yang dianjurkan pada Kurikulum 2013. Model pembelajaran pada Kurikulum 2013 menekankan orientasi pembelajaran berpusat pada siswa (Student Centered) bukan orientasi pembelajaran berpusat pada guru (Teacher Centered).

Berkaitan dengan perangkat pembelajaran yang digunakan pada pembelajaran di MTsN 3 Nganjuk antara lain silabus, RPP, LKS, dan instrumen penilaian berupa lembar soal ulangan akhir bab. LKS yang didapatkan dari penerbit tertentu setelah dianalisis, diketahui bahwa Kompetensi Dasar (KD) LKS yang digunakan belum sesuai dengan KD pada Permendikbud RI Nomor 24 Tahun 2016. Tujuan penelitian dan pengembangan ini adalah menghasilkan perangkat pembelajaran model Inkuiri Terbimbing berbasis potensi lokal yang valid, praktis, dan efektif pada materi Struktur dan Fungsi Jaringan Tumbuhan mata pelajaran IPA siswa kelas VIII.

\section{METODE}

Model penelitian ini adalah model penelitian pengembangan. Penelitian ini dilaksanakan pada Bulan Agustus sampai dengan Bulan Desember 2019. Model pengembangan pada penelitian ini mengadaptasi dari model pengembangan 4-D oleh Thiagarajan, dkk., (1974) yang terdiri atas empat tahap, antara lain define, design, develop, dan disseminate, namun penelitian ini dilakukan pembatasan sampai tahap develop. Tahapan ini secara rinci dapat dilihat pada Tabel 1 dan subjek coba penelitian ini tertera pada Tabel 2. 
Tabel 1. Ringkasan Tahapan Model Pengembangan 4-D

\begin{tabular}{ll}
\hline Tahap & Sub-Tahap \\
\hline Define (Pendefinisian) & a. Front-End Analysis \\
& b. Learner Analysis \\
& c. Task Analysis \\
& d. Consept Analysis \\
Design (Perancagan) & e. Specifying Instructional Objectives \\
& a. Constructing Criterion-Referenced Tests \\
& b. Media Selection \\
c. Format Selection \\
Develop (Pengembangan) & a. Expert Appraisal \\
& b. Developmental Testing \\
\hline
\end{tabular}

(Diadaptasi dari Thiagarajan, dkk., 1974).

Tabel 2. Kriteria Subjek Uji Coba

\begin{tabular}{cclccl}
\hline No & $\begin{array}{c}\text { Validator/ Prakti- } \\
\text { si/ Subjek }\end{array}$ & Profesi & Jumlah (orang) & & \multicolumn{2}{c}{ Kriteria } \\
\hline 1 & Ahli Materi & Dosen & 1 & $\checkmark$ & Ahli dalam materi Struktur Tumbuhan \\
& & Biologi & & $\checkmark$ & Memiliki gelar akademik S2/S3 \\
2 & Ahli Perangkat & Dosen & 1 & $\checkmark$ & Ahli dalam perangkat pembelajaran biologi \\
& Pembelajaran & Biologi & & $\checkmark$ & Memiliki gelar akademik S2/S3 \\
3 & Praktisi Lapangan & Guru & 1 & $\checkmark$ & Guru mata pelajaran IPA di Kelas VIII \\
& & IPA & & $\checkmark$ & Memiliki gelar akademik minimal S1 pada Pendidikan \\
& & & & & Biologi \\
4 & Subjek Uji Coba & Siswa & & & \\
& & & $(\mathrm{L}=8, \mathrm{P}=19)$ & & \\
& & & & & \\
\end{tabular}

Jenis data dalam penelitian dan pengembangan ini adalah data kuantitatif dan kualitatif. Data kuantitatif diperoleh dari angket penilaian validitas silabus, RPP, LKS, dan instrumen penilaian pembelajaran yang diisi oleh ahli perangkat pembelajaran, ahli materi, praktisi lapangan, angket respon siswa, dan nilai hasil belajar siswa. Data kualitatif diperoleh dari komentar dan saran validator dan praktisi lapangan sebagai acuan revisi untuk mendapatkan perangkat pembelajaran yang memenuhi kriteria kelayakan yang baik.

Instrumen yang digunakan dalam validasi perangkat pembelajaran berupa angket validasi, uji coba kepratisan berupa angket yang diisi oleh siswa, dan uji keefektifan berupa lembar soal uji kompetensi dan lembar observasi. Teknik analisis data kuantitatif hasil uji kevalidan dan uji kepraktisan menggunakan persamaan berikut ini.

Keterangan:

$$
\mathrm{P}=\frac{\sum \mathrm{x}}{\sum \mathrm{xi}} \times 100 \%
$$

\footnotetext{
P : Persentase

$\sum \mathrm{x} \quad$ : Jumlah jawaban responden dalam 1 item

$\sum x i \quad$ : Jumlah nilai ideal dalam 1 item
}

(Sumber: Arikunto, 2013)
Data hasil uji keefektifan berupa hasil pembelajaran pada kompetensi ranah sikap, pengetahuan, dan keterampilan. Nilai kompetensi ranah pengetahuan berupa nilai ketuntasan siswa yang akan dibandingkan dengan hasil nilai ketuntasan siswa secara klasikal. Indikator pengembangan perangkat pembelajaran dikatakan efektif apabila $75 \%$ siswa tuntas secara klasikal dari nilai KKM untuk nilai pengetahuannya (Jannah, dkk., 2012). Perhitungan tingkat keefektifan perangkat pembelajaran secara klasikal ditentukan dengan menggunakan rumus sebaga berikut.

Keterangan:

$$
\mathrm{P}=\frac{\sum \text { siswa yang tuntas belajar }}{\sum \text { siswa keseluruhan }} \times 100 \%
$$

$\mathrm{P} \quad$ : Persentase

$100 \%$ : konstanta

\section{HASIL}

Hasil validasi produk pengembangan yaitu perangkat pembelajaran yang terdiri dari silabus, RPP, LKS, dan Instrumen Penilaian (IP) dapat dilihat melalui grafik pada Gambar 1. 


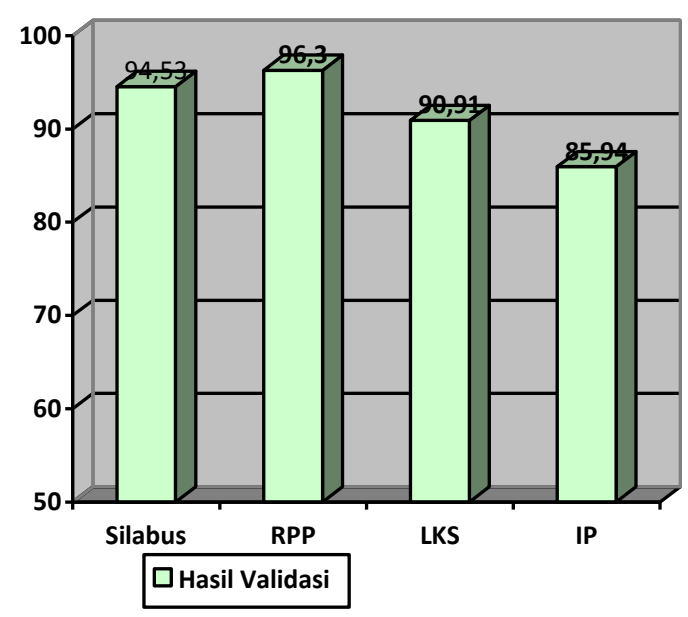

Gambar 1. Hasil Validasi

Hasil uji kepraktisan perangkat pembelajaran dari angket respons siswa sejumlah 27 responden diperoleh persentase rata-rata $88,96 \%$, yang menunjukkan perangkat pembelajaran yang dikembangkan termasuk sangat praktis. Hasil uji keefektifan diperoleh dari keseluruhan nilai kompetensi siswa selama proses pembelajaran, yaitukompetensi sikap spiritual dan sosial, kompetensi pengetahuan, dan kompetensi keterampilan. Ringkasan hasil rerata kompetensi siswa secara keseluruhan dapat dilihat melalui grafik pada Gambar 2.

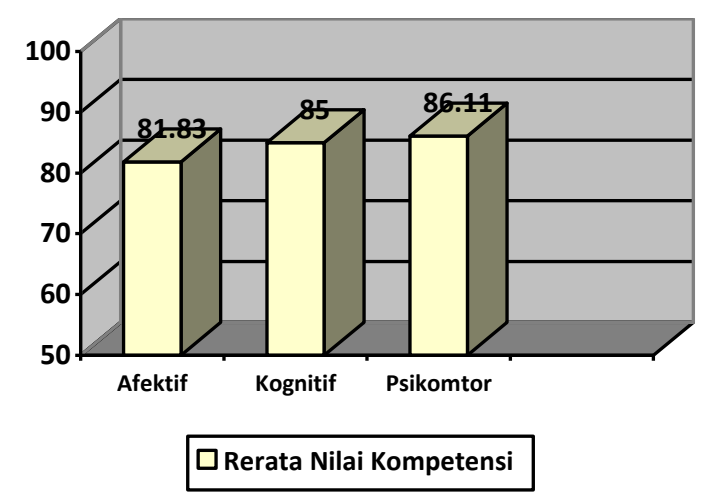

Gambar 2. Rerata Kompetensi Siswa

\section{PEMBAHASAN}

Perangkat pembelajaran dibutuhkan dalam kegiatan pembelajaran, karena dapat menciptakan keteraturan tahapan dalam proses belajar yang berlangsung di sekolah (Winarni,dkk.,2012). Perangkat pembelajaran akan lebih bermakna apabila diko- laborasikan dengan potensi lokal dimana siswa belajar.

Potensi lokal merupakan potensi sumber daya spesifik yang dimiliki suatu daerah meliputi sumber daya alam, manusia, teknologi, dan budaya yang dapat dikembangkan untuk kemandirian nasional. Potensi lokal dapat juga diartikan sebagai pengetahuan dasar yang diperoleh dari kehidupan yang seimbang dengan alam (Sarah \& Maryono, 2014).

Potensi lokal yang ada di lingkungan siswa MTsN 3 Nganjuk berupa potensi bidang pertanian seperti tumbuhan jagung dan cabai. Potensi ini diintegrasikan dengan pengembangan perangkat pembelajaran. Perangkat pembelajaran terdiri dari silabus, RPP, LKS, dan Instrumen Penilaian

Kevalidanan Perangkat Pembelajaran yang Telah Dikembangkan

Rerata hasil validasi perangkat pembelajaran menunjukkan nilai $91,92 \%$ (sangat valid dan layak digunakan dalam pembelajaran). Pembahasan masing-masing bagian perangkat pembelajaran secara rinci tertera pada paparan berikut.

\section{a. Silabus}

Menurut Peraturan Menteri Pendidikan dan Kebudayaan RI Nomor 22 Tahun 2016, silabus dikembangkan berdasarkan Standar Kompetensi Lulusan dan Standar Isi untuk satuan pendidikan dasar dan menengah sesuai dengan pola pembelajaran pada setiap tahun ajaran tertentu. Silabus digunakan sebagai acuan dalam pengembangan Rencana Pelaksanaan Pembelajaran (RPP).

Silabus yang dikembangkan mencakup indentitas mata pelajaran, identitas sekolah, Kompetensi Inti, Kompetensi Dasar, materi pokok, kegiatan pembelajaran, penilaian, alokasi waktu, dan sumber belajar, silabus yang dikembangkan ditambahkan indikator pencapaian kompetensi setelah Kompetensi Dasar. Hal ini bertujuan untuk dapat lebih mudah mengetahui kompetensi yang seharusnya dicapai oleh siswa.

Penyusunan materi pokok dalam silabus ini terdiri dari beberapa bagian yatitu (1) struktur dan fungsi jaringan tumbuhan pada 
organ akar, batang, dan daun, (2) praktikum fotosintesis, dan (3) teknologi yang terinspirasi oleh struktur tumbuhan.

Silabus ini selanjutnya divalidasi oleh validator dosen ahli perangkat pembelajaran dan guru IPA kelas VIII di MTsN 3 Nganjuk sebagai praktisi lapangan. Hasil validasi dari silabus menunjukkan persentase rata-rata skor $94,53 \%$. Hasil tersebut menunjukkan bahwa pengembangan silabus ini memiliki kriteria sangat valid.

Ditinjau dari komentar dan saran, ada beberapa saran dari validator dosen ahli perangkat dan praktisi lapangan yang digunakan sebagai bahan revisi produk, selanjutnya silabus ini digunakan sebagai acuan dalam menyusun Rencana Pelaksanaan Pembelajaran (RPP). Hal ini sesuai dengan pendapat Rohman (2012:123) bahwa silabus bermanfaat bagi guru sebagai pedoman dalam penyusunan perencanaan pelaksanaan pembelajaran dan sebagai pedoman dalam penyelenggaraan sutau proses pembelajaran.

\section{b. $R P P$}

Permendikbud RI Nomor 22 Tahun 2016 menjelaskan bahwa setiap pendidik pada satuan pendidikan berkewajiban menyusun RPP secara lengkap dan sistematis agar pembelajaran berlangsung secara interaktif, inspiratif, menyenangkan, menantang, efisien, memotivasi siswa untuk berpartisipasi aktif, serta memberikan ruang yang cukup bagi prakarsa, kreativitas, dan kemandirian sesuai dengan bakat, minat, dan perkembangan fisik serta psikologis siswa. Rencana Pelaksanaan Pembelajaran disusun berdasarkan Kompetensi Dasar yang dilaksanakan satu kali pertemuan.

Produk perangkat pembelajaran berupa RPP divalidasi oleh validator dosen ahli perangkat pembelajaran dan guru IPA kelas VIII di MTsN 3 Nganjuk sebagai praktisi lapangan. Hasil validasi RPP diperoleh ratarata nilai skor sebesar $96,30 \%$ (sangat valid dan layak digunakan).

\section{c. $L K S$}

Lembar kerja siswa sebagai perangkat pembelajaran yang digunakan sebagai pan- duan untuk siswa dalam melakukan kegiatan praktikum maupun kegiatan diskusi yang disusun sesuai pencapaian indikator siswa tersebut, sehingga siswa memperoleh kemampuan sikap, pengetahuan, dan keterampilan (Fahri, 2012). Pengembangan LKS pada penelitian ini disusun menggunakan pendekatan saintifik dengan model pembelajaran Inkuiri Terbimbing berbasis potensi lokal kabupaten Nganjuk pada materi Struktur dan Fungsi Jaringan Tumbuhan serta Pemanfaatannya dalam Teknologi.

Komponen LKS terdiri dari topik pembelajaran, identitas kelompok, tujuan pembelajaran, orientasi, rumusan masalah, hipotesis, alat dan bahan, prosedur kerja, tabel data, analisis data, kesimpulan, dan daftar pustaka. Hasil validasi rata-rata nilai skor persentase terhadap LKS yang dikembangkan adalah 90,91\% (sangat valid dan layak digunakan).

\section{d. Instrumen Penilaian}

Penialaian dalam pembelajaran adalah proses pengumpulan dan pengolahan informasi untuk mengukur pencapaian hasil peserta didik atau siswa (Permendikbud RI Nomor 23 Tahun 2016). Pengembangan instrumen penilaian pembelajaran yang dilakukan pada penelitian dan pengembangan ini meliputi pengembangan instrumen penilaian kompetensi siswa pada ranah sikap spiritual, ranah sikap sosial, ranah pengetahuan, dan ranah keterampilan.

Prosedur pengembangan instrumen penilaian dimulai dari (a) menetapkan tujuan penilaian dengan mengacu pada RPP yang telah disusun; (b) menyusun kisi-kisi penilaian; (c) membuat instrumen penilaian berikut pedoman penilaian; (d) melakukan analisis kualitas instrumen; (e) dan melakukan penilaian.

Hasil rata-rata skor validasi instrumen penilaian dari kedua validator tersebut adalah 85,94\%. Hasil tersebut menunjukkan bahwa instrumen penilaian pembelajaran yang dikembangkan sangat valid dan layak untuk digunakan dalam pembelajaran. 
Kepraktisan Perangkat Pembelajaran yang Telah Dikembangkan

Hasil pengembangan perangkat pembelajaran yang telah divalidasi oleh validator dan direvisi oleh peneliti selanjutnya diujicobakan pada siswa kelas VIII-ECP.A MTsN 3 Nganjuk sebanyak 27 siswa. Uji coba perangkat pembelajaran dilaksanakan pada 7-14 November 2016 dalam proses pembelajaran dan 19 Nopember 2016 dalam Ujian Kompetensi pengetahuan dan spiritual. Salah satu tujuan dari penelitian adalah untuk mengetahui kepraktisan perangkat pembelajaran yang dikembangkan. Uji kepraktisan ini dapat dilakukan pada saat uji coba perangkat pembelajaran.

Data mengenai uji kepraktisan ini diperoleh dari data hasil angket respon siswa terhadap perangkat yang digunakan selama pembelajaran. Hasil rata-rata skor uji kepraktisan perangkat pembelajaran adalah $88,96 \%$ (sangat praktis).

Perangkat pembelajaran yang dikembangkan sesuai dengan perkembangan pola pikir siswa pada usia 12-19 yang pada usia tersebut anak telah dapat mempertimbangkan kemungkinan fenomena yang akan terjadi (hipotesis), mencari jawaban, menangani masalah dengan fleksibel, menguji hipotesis, dan menarik kesimpulan (Danim: 2010:80) Dengan demikian pemilihan model pembelajaran Inkuiri Terbimbing dalam mengembangkan perangkat pembelajaran sangat sesuai dengan perkembangan pola berpikir siswa dan menjadikan perangkat pembelajaran ini sangat praktis untuk siswa kelas VIII.

\section{Keefektifan Perangkat Pembelajaran yang Telah Dikembangkan}

Hasil uji keefektifan terhadap perangkat pembelajaran materi Struktur dan Fungsi Jaringan Tumbuhan serta Pemanfaatannya dalam Teknologi melalui model pembelajaran inkuiri terbimbing berbasis potensi lokal yang telah dikembangkan menghasilkan rata-rata nilai sebesar 84,31 untuk semua ranah kompetensi pembelajaran. Secara rinci rerata perolehan nilai belajar untuk ranah sikap spiritual sebesar 87,04; ranah sikap sosial sebesar 76,62; ranah pengetahuan sebesar 85,00; dan ranah keterampilan sebesar 86,11 .

Presentase ketuntasan siswa secara klasikal menunjukkan nilai $85,18 \%$. Persentase ketuntasan klasikal menunjukkan bahwa perangkat pembelajaran masih dikatakan efektif sebagaimana ditunjukkan dari hasil penelitian Jannah, dkk., (2012) dijelaskan bahwa suatu produk dikatakan efektif ketika hasil belajar siswa menunjukkan $75 \%$ dari jumlah siswa tuntas secara klasikal. Ketuntasan nilai klasikal yang dicapai siswa tidak lepas dari perangkat pembelajaran yang telah dikembangkan dan digunakan selama proses pembelajaran, sehingga seluruh ranah kompetensi belajar dapat terakomodasi sesuai dengan tingkat kompetensi yang diharapkan.

Kegiatan pembelajaran dengan model Inkuiri Terbimbing berbasis potensi lokal, akan mampu membuat pembelajaran siswa lebih optimal dari keterlibatan secara langsung yang mereka alami. Hal ini sesuai dengan pernyataan DeHaan (2009) bahwa pembelajaran yang dilakukan melalui penemuan dan perolehan pengalaman nyata dengan bantuan alat, bahan, atau media belajar yang lain serta peran guru sebagai fasilitator dalam lingkungan belajar akan memungkinkan siswa memperoleh pengalaman belajar yang optimal. Hal itulah yang menjadikan siswa mampu memperoleh nilai rata-rata hasil belajar klasikal yang tinggi.

Hasil kompetensi siswa yang termasuk kategori tinggi tersebut menunjukkan adanya keberhasilan pengembangan perangkat pembelajaran. Rohman (2012:183) menyatakan bahwa proses pembelajaran dikatakan berhasil apabila dilaksanakan dengan perencanaan yang sangat matang. Setengah keberhasilan yang telah dicapai juga merupakan hasil dari perangkat pembelajaran yang digunakan dalam pembelajaran. Keseluruhan perangkat pembelajaran yang terdiri dari silabus, RPP, LKS, dan instrumen penilaian pembelajaran harus saling berkaitan dengan mengacu indikator pencaipaian kompetensi. 


\section{KESIMPULAN DAN SARAN \\ Kesimpulan}

Perangkat pembelajaran yang dihasilkan memiliki hasil rata-rata uji kevalidan sebesar 91,92\% (sangat valid dan layak digunakan), hasil rerata skor validasi materi pembelajaran adalah 90,28\% (sangat valid dan layak digunakan), dan hasil uji kepraktisan penggunaan perangkat pembelajaran diperoleh persentase rata-rata $88,96 \%$ (sangat praktis digunakan). Data uji keefektifan menunjukkan bahwa skor rata-rata kompetensi siswa sebesar 84,31 dan nilai tersebut telah melebihi nilai KKM MTsN 3 Nganjuk. Presentase ketuntasan siswa secara klasikal menunjukkan nilai $85,18 \%$.

\section{Saran}

Perlu adanya pengembangan perangkat pembelajaran secara lebih lanjut pada materi lain dengan model inkuiri terbimbing atau dengan model pembelajaran lain yang mungkin dapat lebih baik dalam mencapai kompetensi siswa. Media realia berbasis potensi lokal sebaiknya juga dioptimalkan lagi.

\section{DAFTAR RUJUKAN}

Arikunto, S. 2013. Dasar-Dasar Evaluasi Pendidikan Edisi 2. Jakarta: Bumi Aksara.

Bilgin, I. 2009. The Effects of Guided Inquiry Instruction Incorporating a Cooperative Learning Approach on University Students' Achievement of Acid and Bases Concepts and Attitude Toward Guided Inquiry Iinstruction. Academic Journals of Scientific Research and Essay, 4 (10): 10381046.

Danim, S. 2010. Perkembangan Peserta Didik. Bandung: Alfabeta.

DeHaan.R.L. 2009. Teaching Creativity and Inventive Problem Solving in Science. CBE-Life Science Education. Vol 8: 172-181.

Fahri. 2012. Lembar Kerja Siswa (LKS), (Onine), (http://Fahri13.acadeIPA.edu/favicon. ico), diakses 1 Maret 2016.
Fauziyah, R, Abdullah, AG, \& Hakim, D L. 2013. Pembelajaran Saintifik Elektronik Dasar Berorientasi Pembelajaran Berbasis Masalah. Jurnal INVOTE,. 9 (2): 165-178.

Jannah, M., Sugianto, \& Sarwi. 2012. Pengembangan Perangkat Pembelajaran Berorientasi Nilai Karakter melalui Inkuiri Terbimbing Materi Cahaya pada Siswa Kelas VIII Sekolah Menengah Pertama. Journal of Innovative Science Education. 1(1): 5460.

Permendikbud RI Nomor 22 Tahun 2016. Lampiran Peraturan Menteri Pendidikan dan Kebudayaan RI tentang Standar Proses. Jakarta: Kemendikbud RI.

Permendikbud RI Nomor 23 Tahun 2016. Lampiran Peraturan Menteri Pendidikan dan Kebudayaan RI tentang Standar Penilaian Pendidikan. Jakarta: Kemendikbud RI.

Sarah, Siti., \& Maryono. 2014. Pengembangan Perangkat Pembelajaran Berbasis Potensi Lokal untuk Meningkatkan Living Values Peserta Didik SMA di Kabupaten Wonosobo. Jurnal Teknologi Technoscientia, 6:(2). 185-194.

Rohman, M. 2012. Kurikulum Berkarakter Refleksi dan Proposal Solusi terhadap KBK dan KTSP. Jakarta: Prestasi Pustaka Publisher.

Thiagarajan, S., Semmel, D.S., Semmel, M.I. 1974. Instructional Development for Training Teachers of Exceptional Children, A Sourcebook. Bloomington: Indiana University.

Winarni, D., Bintari, S., \& Widiyaningrum, P. 2012. Pengembangan Perangkat Pembelajaran Biologi Berorientasi Life Skills memanfaatkan Bahan Ba$\mathrm{ku}$ Kedelai Loka. Journal of innovative Sciene of Education. (Online), 1(2):119-125, (http://journal.unnes.ac.id/sju/index.p hp/jise/article/view/634/620), diakses 1 Maret 2016. 